\title{
Intergroup Threat as a Mediator of Ethnic Identification and Intergroup Orientations
}

Jelić, Margareta; Uzelac, Ena; Čorkalo Biruški, Dinka

Source / Izvornik: Journal of Language and Social Psychology, 2020, -

Journal article, Accepted version

Rad u časopisu, Završna verzija rukopisa prihvaćena za objavljivanje (postprint)

https://doi.org/10.1177/0261927X20932632

Permanent link / Trajna poveznica: https:/urn.nsk.hr/urn:nbn:hr:131:559855

Rights / Prava: In copyright/Zaštićeno autorskim pravom.

Download date / Datum preuzimanja: 2023-04-26

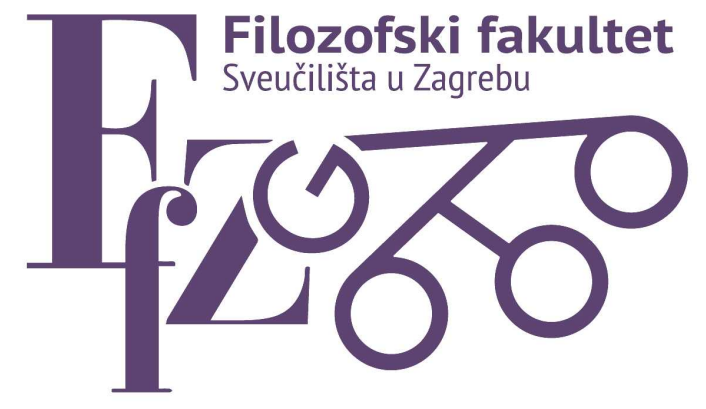

Repository / Repozitorij:

ODRAZ - open repository of the University of Zagreb Faculty of Humanities and Social Sciences
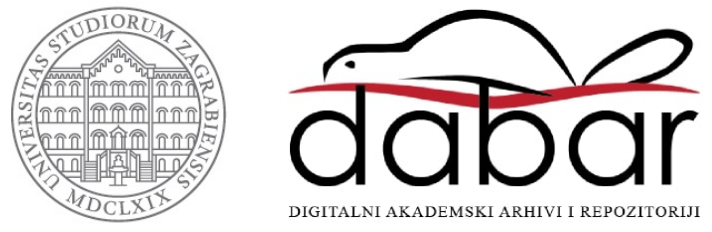


\title{
Intergroup Threat as a Mediator of Ethnic Identification and Intergroup Orientations
}

\author{
Margareta Jelić, Ena Uzelac, and Dinka Čorkalo Biruški
}

Faculty of Humanities and Social Sciences, University of Zagreb

\begin{abstract}
Author Note
Margareta Jelić (ID https://orcid.org/0000-0002-2478-0756

Ena Uzelac (D) https://orcid.org/0000-0001-5104-2612

Dinka Čorkalo Biruški (D) https://orcid.org/0000-0002-2954-4349
\end{abstract}

The authors would like to thank two anonymous reviewers for their valuable feedback on earlier drafts of this article. We would also like to thank Tea Pavin Ivanec, Lana Pehar and Jasmina Tomašić Humer for their contributions in data collection. The research described in this paper was supported by the Croatian Science Foundation, grant number: IP-2014-09-4499. We have no conflicts of interest to disclose.

Correspondence concerning this article should be addressed to Ena Uzelac, Department of Psychology, University of Zagreb, Ivana Lučića 3, 10000 Zagreb, Croatia. Email: euzelac@ffzg.hr 


\begin{abstract}
In Croatia, four minority groups practice their right to education in their respective mother tongues. Relations between the majority and minority groups in the four multi-ethnic communities have developed under different historical circumstances. Thus, in some regions the different language of the minority and the majority group can be perceived as a threat to identity and result in intergroup prejudice and discrimination, whereas in others it might not. In this study, we wanted to examine: a) the mediating effect of perceived threat on the relationship between in-group identification and intergroup orientation, b) whether those relationships are moderated by the group status, and c) contextual specificities, i.e. we wanted to test the model in four different contexts. Results showed that ethnonationalism (rather than ethnic identity) is detrimental for intergroup relations, partially due to its connection to the perception of the outgroup as a threat. Model tests in different contexts revealed some contextual differences.
\end{abstract}

Keywords: minority education, in-group identification, perceived symbolic threat, intergroup anxiety, intergroup orientation 


\section{Intergroup Threat as a Mediator of Ethnic Identification and Intergroup Orientations}

Ethnic diversity and multilingualism become norms in modern societies (Chun, 2016; Darvin \& Norton, 2017). This is why the balance between preserving one's ethnic identity and integration in a wider society is important. As language is one of the most important symbols of ethnic identity (Liebkind, 2010) minorities may feel it is important to be educated in their mother tongue. Although a positive effect of minority-language education is implied, the possible negative effects have been less extensively studied. On the one hand, nurturing one's language and culture might lead to greater endorsement and respect of the rights of other ethnic groups. On the other hand, having schools use minority languages may overemphasize group differences and diminish opportunities for intergroup contact in school. Which outcome is more probable might depend on the similarity of the languages, their social status but also the history of conflict between the majority and the minority group. When groups are in conflict separate minority education may lead to further division among children and a perception of out-group threat. In this paper, we look at the role of perceived threat on the relationship between in-group identification and indicators of intergroup relations in four multi-ethnic communities in Croatia where minority groups practice education in their mother tongues.

Ethnolinguistic identity theory (ELIT) suggests that language is the central aspect of ethnic identity (Giles \& Johnson, 1987) contributing importantly to ethnic identity construction (Hurtado \& Gurin, 1987; Liebkind, 2010; Tong et al., 1999). For minorities, language represents a reminder of cultural heritage and is a key element of their group distinctiveness. Research even shows that ethnic group members identify more closely with those who speak their language than with those who share their cultural background and geographic residence (Giles et al., 1976; Jaspal, 2009). However, the theory of subjective ethnolinguistic vitality (SEV) (Bourhis \& Sachdev, 1984; Giles et al., 1977) emphasizes the need to include social context in the studies of language and identity. Recent meta-analysis (Mu, 2015) supported the general 
effect of the relationship between ethnic identity and language proficiency. Hence, education in mother tongue is very important to ethnic minorities as a way of preserving their ethnic identity (Hurtado \& Gurin, 1987). However, the possible negative effects of minority language education are sometimes neglected (e.g., children belonging to minority groups may use their mother tongue to exclude out-group children from conversations). Consequently, majority group children may become suspicious and anxious, as they cannot understand their minority group peers (Verkuyten, 2005). Recent studies show that language or even accent can be a source of prejudice and discrimination (Hansen \& Dovidio, 2016; Hansen et al., 2014). Whether such negative outcomes will take place in a specific community probably depends on the strength and type of own group ethnolinguistic identification.

Attachment to an ethnic group may have different consequences for intergroup relations. In the Croatian social context, nation and ethnicity overlap for the majority Croats and these terms have been used interchangeably, referring both to a shared heritage and to culture, but also to a political community. However, for minority groups their dual identity is recognized by the Croatian Constitution, acknowledging their cultural and ethnolinguistic specificity but also including them in a common political community of citizenship. According to social identity theory, (SIT; Tajfel \& Turner, 1979) people derive their identity and self-worth from the groups they belong to. This in-group attachment helps explain why people adhere to in-group norms and show in-group bias. However, in-group positivity and out-group derogation are not reciprocally related (Brewer, 2007). It is possible that even high in-group identification is unrelated to the relations with relevant out-groups. However, attachment to and love for one's nation have to be distinguished from ethnonationalism which presupposes that one's nation is superior to other nations (Mummendey et al., 2001; Schatz et al., 1999). Hence, nationalism can be seen as a negative consequence of national identity and involves moral superiority, idealization and glorification of the in-group and distrust of out-groups (Blank \& Schmidt, 2003). 
Thus, to understand intergroup relations it may be important to consider the mechanisms underlying this link between identity and intergroup behavior. One of the most prominent explanations of such a link is intergroup threat. Integrated threat theory (ITT, Stephan \& Stephan, 2000) postulates that threat associated with an out-group can increase negative attitudes and even negative behaviors toward this group (Croucher, 2018; Stephan et al., 2009). ITT distinguishes four different types of threat from a specific out-group: realistic threat, symbolic threat, intergroup anxiety, and negative stereotypes (Stephan et al., 2002). Symbolic threat involves threats to in-group identity, (i.e., to the group's worldview, morals, values, and standards). A meta-analysis showed that in-group identification was more strongly related with the perception of symbolic than to realistic threat (Riek et al., 2006). This finding was supported in post-conflict settings of Croatia corroborating symbolic threat as an important correlate of the in-group identification (Löw Stanić, 2014). Intergroup anxiety refers to feelings of threat people experience during intergroup interactions because they are worried about being embarrassed, rejected and misunderstood by the out-group (Stephan \& Stephan, 1985). While other types of intergroup threat are more cognitive in nature, intergroup anxiety captures the affective reactions to the out-group.

\section{Ethnolinguistic Vitality of Language Groups in the Study}

The last census in Croatia showed that slightly less than $10 \%$ of the population was made up of minority groups (Croatian Bureau of Statistics, 2011) while the Croatian Constitution recognizes 22 ethnic minorities across different regions. We conducted our study in four multiethnic communities in Croatia where ethnic minorities are large enough to exercise their constitutional right to be educated in their own minority languages (the Serb-Croat context in the town of Vukovar and surroundings, the Italian-Croat context in several towns in Istria County, the Hungarian-Croat context in the town of Osijek and surroundings, and the Czech-Croat context in the town of Daruvar and surroundings). In each of the regions a single minority has 
been more concentrated than others: in Vukovar these are Serbs (15.5\% vs. $80.2 \%$ of Croats), in Istria Italians ( $6.03 \%$ vs. $83.82 \%$ of Croats), in Osijek region Hungarians $(2.7 \%$ vs. $87 \%$ of Croats), and in Daruvar region Czechs (5.25\% vs. $86.82 \%$ of Croats).

Minority groups in these regions either go to separate schools from the Croatian majority or are schooled in separate classrooms (Čorkalo Biruški et al., 2019). Though all four minority groups have preserved their ethnolinguistic vitality, a variety of historical and cultural factors have shaped different majority-minority dynamics in these regions. One dimension to compare our research contexts is the linguistic similarities between Croatian and the respective minority language. Similar languages might ensure easier integration into Croatian society, but also may lead to a lack of positive distinctiveness between the two groups in question (Turner, 1975). From that perspective, Serbian and Czech as Slavic languages are more similar to the Croatian language (especially Serbian), whereas Hungarian and Italian are very different from Croatian. Furthermore, status of the minority language is also important: the higher the status of the language, the more the ethnolinguistic vitality of the groups is likely to be preserved. For example, the Italian language has a high status (Hržica et al., 2011) and many children in Croatia learn Italian as their second language (Balen, 2015). Conversely, Hungarian is considered more difficult to learn. Moreover, the linguistic community of Hungarians is rather small and fairly isolated and therefore majority members may perceive little social benefits from learning Hungarian. However, at the same time physical isolation has made it easier for Hungarians to preserve their ethnolinguistic vitality while also challenging their integration into wider society. As for the Czech language, its native speakers are also concentrated in one particular region; however, the majority and minority exchange has been much more intensive over the course of history. Thus, contemporary Czech language used by minority in Daruvar region is strongly influenced by the Croatian language. 
The third dimension of comparison is the geographical distance of minority group members' kin-state. Whereas Italy, Serbia and Hungary are neighboring countries to Croatia, this is not a case with the Czech Republic. Thus, being close to the kin-state can make minority more attached to its ethnolinguistic identity and less motivated to integrate into Croatian society. This strategy may be perceived by majority Croats as threatening. Finally, the fourth dimension of comparison is the history of conflict between groups. From this point of view, the Vukovar region is different from the rest because of the recent conflict between Croats and Serbs, and the tension between the two groups is still present. On the opposite end is the Czech-Croat context with no history of majority-minority conflict. As for Italians and Hungarian, the past conflicts with Croats are likely considered to be irrelevant.

These different multi-ethnic contexts offer an opportunity to gain a deeper understanding of the role of minority language education in shaping intergroup relations of pupils. We argue that the language of education further enhances identification with one's ethnic group and makes it more salient in everyday life. Moreover it is also possible that by making ethnic identity more salient it emphasizes the role of ethnonationalism in intergroup relations. Moreover, minority language education might enhance perceived intergroup threat in both majority and minority groups living in the same community.

\section{Aim of the Study}

Drawing on SIT and ITT perspectives in the context of minority education in Croatia, we looked at the mediating effect of symbolic threat and intergroup anxiety in the relationship between in-group identification (ethnic identification and ethnonationalism), and negative and positive out-group orientation (i.e. behavioral intentions to discriminate and to act prosocially towards out-group members). Furthermore, we explored if the group status moderates this relationship (see Figure 1). We tested these models in four social contexts in Croatia. 
Figure 1

Theoretical model of moderated mediation

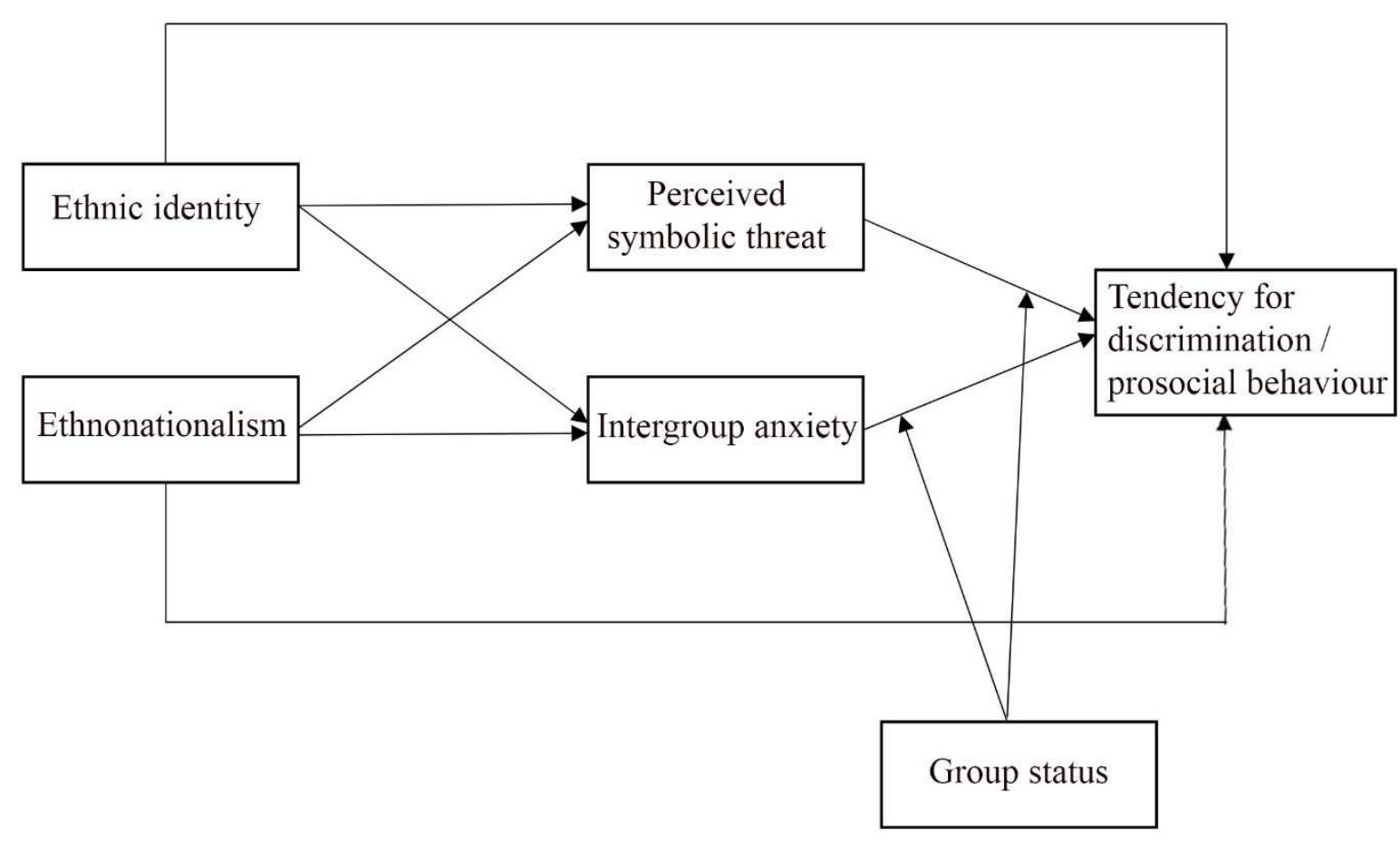

Based on previous studies suggesting that ethnonationalism, rather than ethnic identity per se, is detrimental for intergroup relations (Brewer, 1999; Čorkalo \& Kamenov, 2003; Jelić et al., 2014; Penic et al., 2017), we expect ethnonationalism to be positively related to out-group derogation and negatively to prosocial tendencies towards the out-group via greater perception of symbolic threat and intergroup anxiety. The inclusion of two different types of intergroup threat will enable us to see whether cognitive or affective path plays a more important role in intergroup relations.

However, the link between ethnic identification and intergroup orientation is less easy to predict due to the mixed results in previous studies (Costarelli \& Calli, 2004; Ruttenberg et al., 1996). We argue that introducing both measures of ethnic identification and ethnonationalism simultaneously would separate their unique contribution to intergroup behaviour, and that ethnic identification might even be associated with positive out-group outcome via lesser perception of symbolic threat and intergroup anxiety. 
In addition, we propose that the group status (majority or minority) moderates the link between intergroup threats and intergroup behaviour. Based on ITT's assumptions, we could expect our models to account for more variance among members of the majority group. However, results corroborating this assumption have not been consistent suggesting that it all depends on the type of threat, type of behavior and specific social context (Löw Stanić, 2014).

Finally, following the recent developments in intergroup contact theory (Hodson et al., 2013) we decided to include measures of both positive and negative intergroup behavior instead of focusing on just negative behaviors.

\section{Method}

\section{Participants}

A total of 1467 students participated (642 males, 782 females, and 43 who did not specify their gender) from 22 elementary $(n=731)$ and 10 high schools $(n=736)$, aged from 11 to 19 years $(M=15.19 ; S D=1.991)$. We used education language as a proxy of ethnicity in four different multi-ethnic settings in Croatia. The sample included 238 pupils in education on Serbian language, 97 pupils educated in Hungarian language, 137 pupils in Czech language education, 250 pupils in education in Italian language, and 745 majority Croats.

\section{Materials}

\section{Predictor variables}

Ethnic identity was assessed by five items adapted from Doosje et al. (1995). The responses were indicated on a five-point scale ranging from highly disagree (1) to highly agree (5). Higher values indicated a stronger ethnic identity. The reliability of the scale in this research was $\alpha=.90$ for the whole sample (ethnic majority: $\alpha=.90$; ethnic minorities: $\alpha=.91$ ).

Ethnonationalism was assessed by three items used in Čorkalo and Kamenov (2003). The responses were indicated on a five-point scale ranging from highly disagree (1) to highly agree (5). Higher values indicated more pronounced ethnonationalism. The reliability of the scale in 
this research was $\alpha=.79$ for the whole sample (ethnic majority: $\alpha=.79$; ethnic minorities: $\alpha=$ $.79)$.

\section{Mediator variables}

Perceived symbolic threat was measured by five items adapted from Čorkalo Biruški (2011). Participants assessed their agreement on a four-point scale ranging from highly disagree (1) to highly agree (4). Higher values indicated more perceived intergroup symbolic threat. The reliability of the scale in this research was $\alpha=.83$ for the whole sample (ethnic majority: $\alpha=.85$; ethnic minorities: $\alpha=.80$ ).

Intergroup anxiety was measured using a six-item scale modified from Stephan and Stephan (1985) asking participants how they would feel when interacting with members of the other ethnic group. The out-group for minorities was always Croats, and for Croats the out-group was the respective minority group in each context. Participants responded on a five-point scale ranging from not at all (1) to extremely (5). The reliability of the scale in this research was $\alpha=$ .80 for the whole sample (ethnic majority: $\alpha=.81$; ethnic minorities: $\alpha=.78$ ).

\section{Outcome variables}

The tendency for out-group discrimination is a measure of behavioral intent, adapted from Čorkalo Biruški and Ajduković (2007). Participants were provided with descriptions of eight everyday situations and asked if they would choose their in-group member in order to complete the task described. The total number of positive (coded as 1 ) and negative (coded as 0 ) responses was summed, ranging from zero to eight. Higher numbers indicated a more pronounced tendency to discriminate against the out-group. The reliability of the scale was $\alpha=.80$ for the whole sample (ethnic majority: $\alpha=.83$; ethnic minorities: $\alpha=.77$ ).

The tendency for out-group prosocial behavior is a measure developed by Štambuk and Čorkalo Biruški (2011). It consisted of five items that asked participants how they would act in different situations where members of one's in-group bully members of the out-group. Participants had to 
indicate their most likely reaction on a four-point scale, support them or join them (1), ignore them (2), ask them to stop (3), and ask my peers to help me to make it stop (4). Higher results indicated a more pronounced tendency to act prosocially. The reliability of the scale was $\alpha=.86$ for the whole sample (ethnic majority: $\alpha=.89$; ethnic minorities: $\alpha=.83$ ). Socio-demographics of age, gender, nationality, school and grade were also included in the questionnaire.

See supplementary online material, Appendix A, for more comprehensive list of items.

\section{Procedure}

Ethical approval was granted by the university Institutional Review Board. The questionnaires were administered in groups, during regular class hours. Participation was voluntary and parental permissions were obtained for students under the age of 14. All questionnaires were completed anonymously and were administered in the native tongues of the students. Czech pupils completed the questionnaire in Croatian as per advice of school principals whereas in all other contexts the vast majority of pupils completed the questionnaire in their minority language. This confirmed the ethnolinguistic identification of the pupils in our sample.

\section{Analytic Procedure}

The main analyses in this study were conducted in R (R core team, 2018) in the laavan package (Rosseel, 2012). We specified two theoretical models for two outcome variables. In the Model A, we regressed the tendency to discriminate, and in the Model B, tendency to act prosocially, on perceived symbolic threat, intergroup anxiety, ethnic identity and ethnonationalism. Then, we regressed perceived symbolic threat and intergroup anxiety on ethnic identity and ethnonationalism. Including both predictors in one model made it possible to control for the direct and indirect effects of each predictor on outcome variables (see Figure 1). To calculate confidence intervals for direct and indirect effects, we used the bias corrected and accelerated bootstrap method $(\mathrm{BCa})$, relying on 5000 replacement samples (Preacher \& Hayes, 
2008). Given that our original sample size is large enough, bootstrapping by the BCa method enables us to get reliable confidence interval estimate (Carpenter \& Bithell, 2000; Crawley, 2007; Puth et al., 2015).

\section{Results and Discussion}

\section{Descriptive statistics and correlations}

Means, standard deviations, and correlations are presented in Table $1^{1}$. Since the study was conducted in multi-ethnic communities where ethnicity is highlighted by separate minority schooling, ethnic identification is highly prominent. Perceived symbolic threat, intergroup anxiety and tendency to discriminate were low, while ethnonationalism scores were just below the scale midpoint. Conversely, the tendency for prosocial behavior was high. The significant correlation coefficients were all in the expected direction. The correlation coefficients between ethnic identity and ethnonationalism $(r=.52, p<.001)$, as well as between perceived symbolic threat and intergroup anxiety $(r=.51, p<.001)$, were moderate in size, suggesting that these measures capture different, yet related, forms of ethnic group attachment, and types of threat.

\section{Moderation effect of group status (moderated mediation)}

Separate multiple group path analyses for group status tested the mediation path model on separate samples of majority and minority participants. Group status was a hypothesized moderator for indirect effects in both A and B models. Multiple group analysis enabled us to compare regression coefficients across groups defined by a dichotomous moderator. We assessed the moderation effect by comparing the fit of two nested models for each outcome variable. First we specified an unconstrained model in which all regression paths were allowed to differ between the groups (no paths group invariant), and then we specified a constrained model in which all regression paths were equal between the groups (all paths group invariant). We employed a chi-square difference test to see if any paths differ between the unconstrained and

\footnotetext{
${ }^{1}$ Table 1 is in Appendix B in supplementary online material.
} 
constrained models. In both A and B models, the fit of these models did not differ significantly compared to the constrained models, indicating there is no moderation effect (see Table $3^{2}$ ).

\section{Mediation models}

Since we found no significant differences in regression coefficients between majority and minority group members, we will interpret our models for the combined sample.

The Model A column in Table $2^{3}$ shows the total, direct and indirect effects for the tendency to discriminate against the out-group. Overall, the mediation path analysis was conducted on data from $N=986$ and the model explained $24.5 \%$ of the variance in the outcome variable. As for direct effects, ethnonationalism was significantly positively related to the tendency to discriminate, while the effect of ethnic identity was not significant. Furthermore, the indirect effects of both ethnic identification and ethnonationalism via both forms of intergroup threat were significant. However, these mediation effects were in the opposite direction. That is, the more participants were attached to their ethnic group, the less threatened and anxious they felt when interacting with members of the other ethnic group. These lower levels of threat and anxiety reduced their tendency to discriminate against the out-group, suggesting that a sense of ethnic belonging might even serve as a protective factor in multi-ethnic context. However, the more participants believed their ethnic group was superior to other groups, the more threatened and anxious they felt towards the out-group and consequently were more prone to discriminate against it (Figure 2).

The Model B column in Table 2 shows the total, direct and indirect effects for the tendency for prosocial behavior towards the out-group. Overall, the mediation path analysis was conducted on data from $N=985$ and the model explained $22.5 \%$ of the variance in the outcome variable. Looking at the direct effects, ethnonationalism was negatively and ethnic identity was positively related to prosocial behavior. Furthermore, the indirect effects of both ethnic identity

\footnotetext{
${ }^{2}$ Table 3 is in Appendix B in supplementary online material.

${ }^{3}$ Table 2 is in Appendix B in supplementary online material.
} 
and ethnonationalism via both forms of intergroup threat were significant. Again, these mediation effects were in the opposite direction. Results showed that the more participants were attached to their ethnic group, the less anxiety they would feel when interacting with members of the other ethnic group, which in turn motivated them to act prosocially towards them. This finding further emphasizes protective role of the ethnic identity. On the other hand, the more participants believed their ethnic group was superior to other groups, the more threatened and anxious they felt towards the out-group and consequently were less prone to act prosocially (Figure 3).

Figure 2

Path diagram of mediation model for the whole sample, Model A

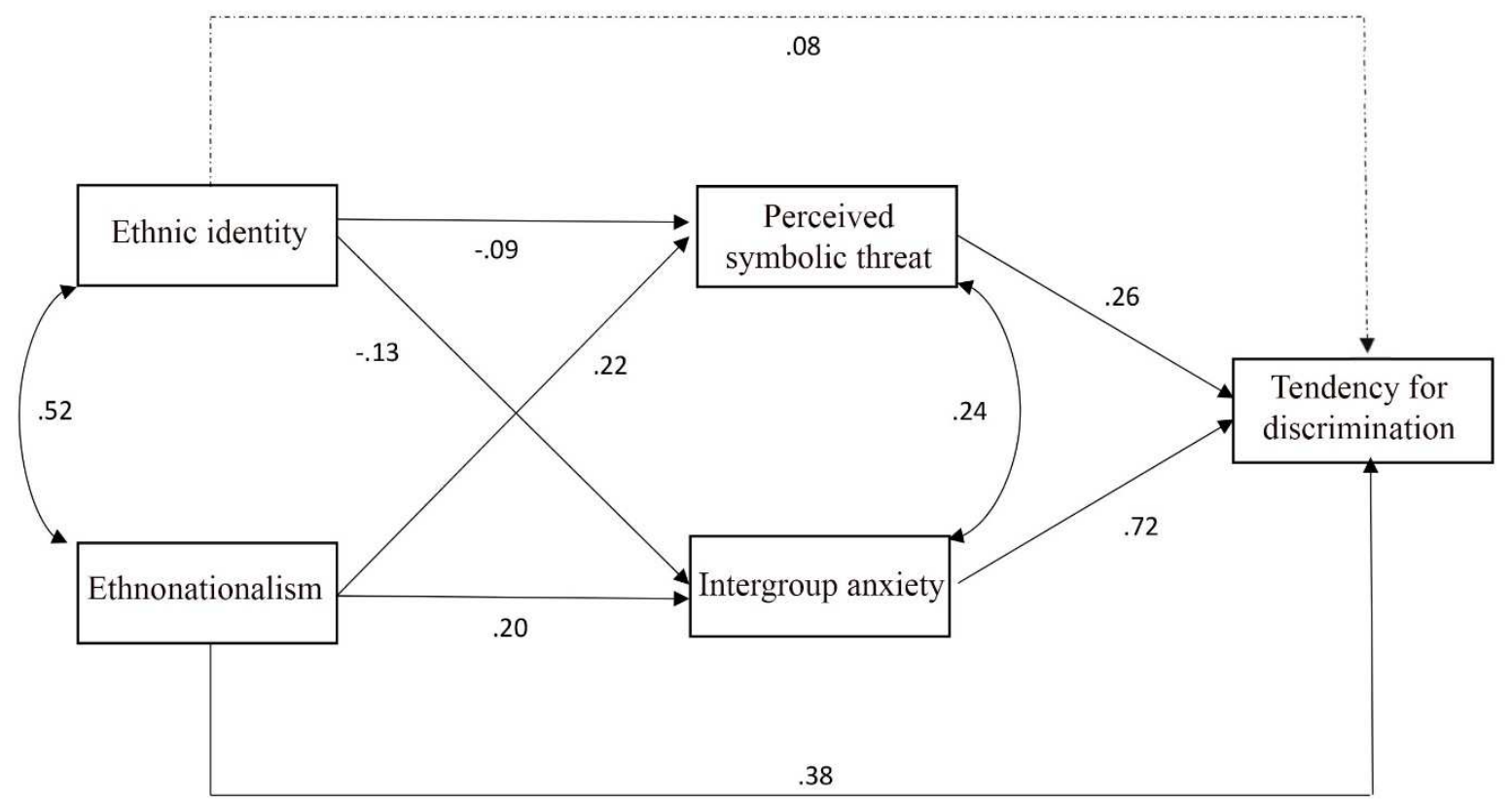

Note. Path coefficients are standardized regression weights. Path coefficients displayed with solid lines are significant, 95\% confidence intervals did not include zero. Path coefficients displayed with dotted lines are nonsignificant. Model explained $24.5 \%$ of the variance. 
Figure 3

Path diagram of mediation model for the whole sample, Model B

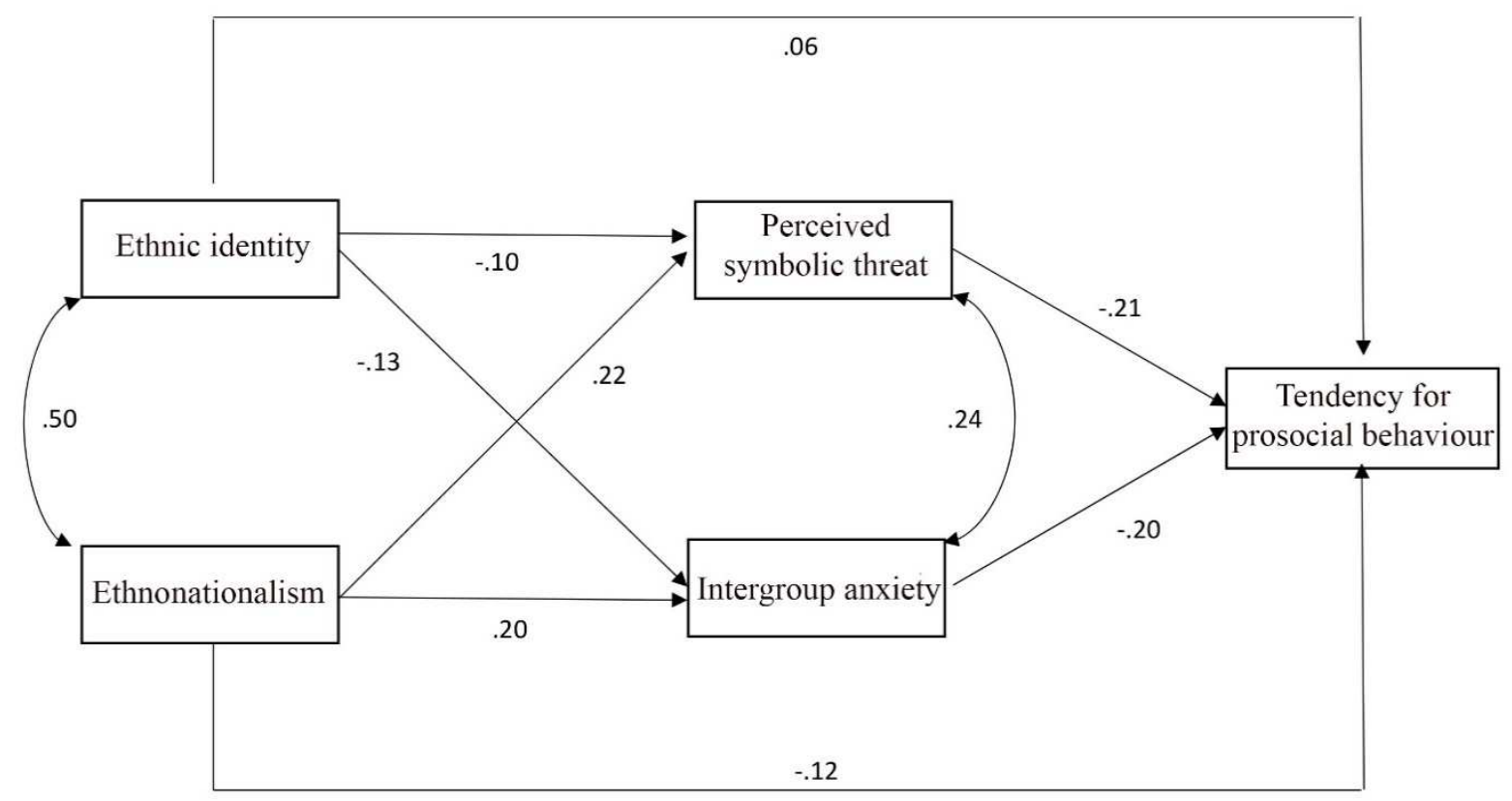

Note. Path coefficients are standardized regression weights. Path coefficients displayed with solid lines are significant, 95\% confidence intervals did not include zero. Path coefficients displayed with dotted lines are nonsignificant. Model explained 22.5\% of the variance.

To summarize, the overall models provided convincing evidence for the partial mediation of intergroup threats on the relationship between in-group identification and out-group orientations. However, the results indicate the importance of distinguishing between different forms of ethnic attachment: sense of belonging to one's ethnic group, (i.e., ethnic identification), and viewing the in-group as superior to other groups, (i.e. ethnonationalism). It seems that it is ethnonationalism that is detrimental for intergroup relations, partially due to its connection with the perception of the out-group threat. Perceived symbolic intergroup threat and intergroup anxiety are serious obstacles for intergroup relations -by facilitating out-group discrimination and by inhibiting prosocial behavior towards the out-group. These effects did not differ between majority and minority. 


\section{Mediating Role of Intergroup Threat in Different Social Contexts}

We tested our models in four multi-ethnic contexts in Croatia with Croats as majority and Serbs, Hungarians, Czechs and Italians as minority groups. We expected to confirm the proposed path models and group status as a moderator.

Separate multiple group path analyses for group status tested the mediation path model on separate samples of majority and minority group members in each social context. As shown in Table $4^{4}$, the proposed moderation effect of group status was confirmed only in the Czech-Croat context. However, this context is also the only context in which our mediation models were not confirmed, meaning that intergroup threat did not mediate relationship between in-group identification and intergroup orientations in either of samples. Regarding other social contexts, group status was not a moderator so we interpret the models for the combined sample of Croats and the respective minority group in each of the contexts. Summarized coefficients for each of the structural paths can be seen in Figures $4-9^{5}$.

In all contexts, the indirect effect of ethnonationalism via intergroup anxiety was significant for both the tendency to discriminate against the out-group (positively) and the tendency to act prosocially towards the out-group (negatively). The more participants believed their ethnic group was superior to other groups, the more anxious they felt towards the out-group and consequently more prone to discriminate against them, and the less likely they were to act prosocially. Additionally, in the Serb-Croat and in the Italian-Croat contexts, the indirect effect of ethnic identification via intergroup anxiety was significant for both the tendency to discriminate (negatively) and the tendency to act prosocially (positively). The more participants were identified to their in-group, the less anxious they felt towards the out-group, and consequently were more prone to act prosocially, and less prone to discriminate against them. Regarding perceived symbolic threat, results showed that in the Serb-Croat context the indirect

\footnotetext{
${ }^{4}$ Table 4 is in Appendix B in supplementary online material.

${ }^{5}$ Figures 4-9 are in Appendix $\mathrm{C}$ in supplementary online material.
} 
effect of ethnonationalism via perceived symbolic threat was significant for the tendency to act prosocially (positively), while in the Italian-Croat context the indirect effects of both ethnic identification (negatively) and ethnonationalism (positively) via perceived symbolic threat were significant for the tendency to discriminate.

\section{General Discussion}

In this paper, we explore multi-ethnic communities where minority groups exercise their right to minority education. We hypothesized that this context would influence ethnic identification and intergroup attitudes and behavior. The present study contributes to the field by exploring both positive and negative out-group orientations. As expected, perceived threat reduces positive and facilitates negative intergroup behavior. Our results also confirmed that perceived intergroup threat mediates the relationship between in-group identification and positive and negative out-group orientation. Moreover, intergroup anxiety and symbolic threat were both mediators of this relationship.

The study also confirmed the importance of distinguishing between two types of in-group attachment. Our findings show that ethnic identity and ethnonationalism have different impacts on the perception of intergroup threat. When controlling for ethnonationalism, ethnic identity as a measure that is not confounded with in-group bias and superiority issues is related to a lower out-group threat. Moreover, while ethnonationalism has a positive direct effect on out-group discrimination, ethnic identity does not. The opposite holds for prosocial behavior towards the out-group members. Thus, our findings are in line with others emphasizing that it is ethnonationalism, rather than sense of belonging per se, that is detrimental for intergroup relations (Brewer, 2007; Roccas et al., 2006).

Contrary to our expectations, group status did not moderate the relationship between threat and intergroup orientations. It is possible that group status is more relevant for intergroup contact than for in-group attachment. Another possibility is that the children from the majority 
and the minority group in the same community are more similar, as they have not yet adhered to social norms as adults did (Low Stanić, 2014). Future studies should compare results from children and adults from both groups to investigate whether children function more as the adults from the majority or as the adults from minority group.

We also tested the intergroup threat model on the four subsamples, in each of the four contexts of our study. Findings show that context does play a role, but the main assumptions of the model still hold, except in the Czech-Croat context. This context is highly integrated, and it is even possible that assimilation of the minority is in progress. Namely, this was the only context in which minority group respondents chose to complete the survey in Croatian, which in itself might have influenced their results by making them aware of their identity as Croatian citizens. In addition, ethnic identification as a Czech seems to be more of a cultural fact than an identity issue. We argue that in the Czech-Croat context there are no status differences, as present in other contexts of our study. Hence, it may be that in this context, there are more harmonious minority-majority relations. Therefore, the intergroup threat model may not be relevant here because perceived intergroup threat is low and thus does not affect intergroup relations.

In the remaining three contexts ITT model was confirmed, (i.e., we found no substantial differences between specific minorities, which is itself a finding that highlights the salience of ethnonationalism effect compared to ethnic identity effect.) This finding suggests a strong link between the glorification of one's group and negative out-group emotions (i.e. intergroup anxiety), which in turn results in a stronger tendency to discriminate against out-group members, and a lower tendency to act prosocially toward the out-group. The effect of ethnic identity was less consistent and opposite to the effects of ethnonationalism. In the same vein, it seems that symbolic threat has weaker impact than intergroup anxiety; indirect effects via intergroup anxiety were found in all contexts for both outcome variables, while indirect effects via perceived symbolic threat were significant only in the Serb-Croat context for the tendency to act 
prosocially, and in the Italian-Croat context for the tendency to discriminate. This suggests that emotions may be more important in intergroup contexts than cognitive factors, but this assumption should be tested in future studies.

Furthermore, the greatest variance in intergroup orientation was explained in the SerbCroat context (the most conflicted of the four communities), followed by the Hungarian-Croat context, and the least in the Italian-Croat context. Moreover, for the most harmonious CzechCroat context the model did not hold. So it seems that contextual differences are based on the dimension of conflict versus harmony, and the model is best suited for more conflicted and not for more harmonious setting. These findings reflect different intergroup dynamics of language groups in the four different contexts. It is possible that in the more integrated settings both negative and positive intergroup behaviors are determined by factors we did not include in this study, such as school and community norms, social identity based on attachment to the community, town or region, instead of one's ethnic group. However, this should be further explored in future studies.

\section{Conclusions}

Based on these results, we have several recommendations for changes in school systems in multi-ethnic communities. Firstly, schools should aim to encourage a healthy attachment to one's own ethnic group, without undermining others, and at fostering a dual identity, where each group may show how it contributes to a unified identity, (e.g., belonging to a common school, place or country). For instance, minority students should be able to decorate schools for their main holidays and make some presentations or plays to talk about their culture to Croats, and vice versa. Teachers should talk with their students about how other cultures enrich community and organize multicultural events. Students should feel free to talk about their ethnicity and find similarities and differences between them. Such an approach, as shown by Riek and colleagues (2010), leads to a lower level of perceived intergroup threat. Furthermore, schools in a multi- 
ethnic community should be a place of appreciation of diversity (thus reducing the symbolic threat) and learning about diversity (thus reducing intergroup anxiety because the out-group is no longer unknown), as well as a safe environment for children's development (Childs, 2017). In order for this to be accomplished it is necessary to develop joint extracurricular activities where children from both groups can learn from and about each other and work together as suggested by intergroup contact theory. Especially useful would be to encourage learning of both languages in multi-ethnic communities and to treat both these languages as the languages of the region, as a cultural heritage and a resource, and a source of community pride (Čorkalo Biruški et al., 2019). A first step in that direction would be to investigate attitudes towards majority and minority languages in each community so the space for attitudinal change can be established.

This study has shown that ethnonationalism and not ethnic identity is associated with negative intergroup outcomes. Thus, as ethnonationalism is based on the incorrect and generalized belief that one's own group is better than the others, we believe that critical thinking should be highly encouraged and taught in the schools. Reducing ethnonationalism and at the same nurturing appreciation of one's own ethnic group might then lead to a positive feeling of ethnic pride without the negative consequences, such as intergroup threat and anxiety connected to the out-group. 


\section{References}

Balen, M. (2015, May 6). Znate li koliko jezika govore Hrvati? [Do you know how many languages do Croats speak?] Dnevnik.hr. https://dnevnik.hr/vijesti/hrvatska/koliko-jezikagovore-hrvati---383845.html

Blank, T., \& Schmidt, P. (2003). National identity in a united Germany: Nationalism or patriotism? An empirical test with representative data. Political Psychology, 24(2), 289312. https://doi.org/10.1111/0162-895x.00329

Bourhis, R. Y., \& Sachdev, I. (1984). Vitality perceptions and language attitudes: Some Canadian data. Journal of Language and Social Psychology, 3(2), 97-126. https://doi.org/10.1177/0261927X8400300202

Brewer, M. B. (1999). The psychology of prejudice: In-group love or out-group hate? Journal of Social Issues, 55(3), 429-444. https://doi.org/10.1111/0022-4537.00126

Brewer, M. B. (2007). The importance of being we: Human nature and intergroup relations. American Psychologist, 62(8), 728-738. https://doi.org/10.1037/0003-066X.62.8.728

Carpenter, J., \& Bithell, J. (2000). Bootstrap confidence intervals: When, which, what? A practical guide for medical statisticians. Statistics in Medicine, 19(9), 1141-1164. https://doi.org/10.1002/(SICI)1097-0258(20000515)19:9<1141::AID-SIM479>3.0.CO;2-F

Childs, K. (2017). Integrating multiculturalism in education for the 2020 classroom. Journal for Multicultural Education, 11(1), 31-36. https://doi.org/10.1108/jme-06-2016-0041

Chun, C. W. (2016). Exploring neoliberal language, discourses and identities. In S. Preece (Ed.), The Routledge handbook of language and identity ( $1^{\text {st }}$ ed., pp. 558-571). Routledge. https://doi.org/10.4324/9781315669816

Costarelli, S., \& Calli, R. M. (2004). Self-directed negative affect: The distinct roles of in-group identification and out-group derogation. Current Research in Social Psychology, 10, 13-27.

Crawley, M. J. (2007). The R book. Wiley. 
Croatian Bureau of Statistics. (2011). Census of population, households and dwellings in 2011: Population by ethnicity. https://www.dzs.hr/Hrv/censuses/census2011/censuslogo.htm

Croucher, S. (2018). Integrated threat theory. In H. Giles \& J. Harwood (Eds.), The Oxford encyclopedia of intergroup communication (Vol. 1., pp. 627-635). Oxford University Press.

Čorkalo Biruški, D. (2011). Djeca i međuetnički odnosi u zajednici [Children and inter-ethnic relations in community]. Unpublished project documents. Faculty of Humanities and Social Sciences.

Čorkalo Biruški, D., \& Ajduković, D. (2007). Separate schools - a divided community: The role of the school in post-war social reconstruction. Review of Psychology, 14(2), 93-108.

Čorkalo, Biruški D., Jelić, M., Pavin Ivanec, T., Pehar, L., Uzelac, E., Rebernjak, B., \& Kapović, I. (2019). Obrazovanje nacionalnih manjina i međuetnički stavovi u četiri višeetničke zajednice u Hrvatskoj: stanje, izazovi, perspektive [Education of national minorities and inter-ethnic attitudes in four multi-ethnic communities in Croatia: state, challenges, perspectives] [Brochure]. The Friedrich-Ebert-Stiftung foundation.

Čorkalo, D., \& Kamenov, Ž. (2003). National identity and social distance: Does in-group loyalty lead to out-group hostility? Review of Psychology, 10(2), 85-94.

Darvin, R., \& Norton, B. (2017). Language, identity, and investment in the twenty-first century. In T. L. McCarty \& S. May (Eds.), Language policy and political issues in education (pp. 1-15). https://doi.org/10.1007/978-3-319-02320-5_18-2

Doosje, B., Ellemers, N., \& Spears, R. (1995). Perceived intragroup variability as a function of group status and identification. Journal of Experimental Social Psychology, 31, 410-436.

Giles, H., Bourhis, R. Y., \& Taylor, D. M. (1977). Towards a theory of language in ethnic group relations. In H. Giles (Ed.), Language, ethnicity and intergroup relations (pp. 307-348). Academic Press.

Giles, H., \& Johnson, P. (1987). Ethnolinguistic identity theory: A social psychological approach 
to language maintenance. International Journal of the Sociology of Language, 1987(68), 69-100. https://doi.org/10.1515/ijsl.1987.68.69

Giles, H., Taylor, D. M., Lambert, W. E., \& Albert, G. (1976). Dimensions of ethnic identity: An example from Northern Maine. Journal of Social Psychology, 100(1), 11-19. https://doi.org/10.1080/00224545.1976.9711902

Hansen, K., \& Dovidio, J. F. (2016). Social dominance orientation, nonnative accents, and hiring recommendations. Cultural Diversity and Ethnic Minority Psychology, 22(4), 544-551. https://doi.org/10.1037/cdp0000101

Hansen, K., Rakić, T., \& Steffens, M. C. (2014). When actions speak louder than words: Preventing discrimination of nonstandard speakers. Journal of Language and Social Psychology, 33(1), 68-77. https://doi.org/10.1177/0261927X13499761

Hodson, G., Hewstone, M., \& Swart, H. (2013). Advances in intergroup contact: epilogue and future directions. In G. Hodson \& M. Hewstone (Eds.), Advances in intergroup contact (pp. 262-305). Psychology Press.

Hržica, G., Padovan, N., \& Kovačević, M. (2011). Društvenojezični utjecaj na dvojezičnost hrvatske dvojezične zajednice u Istri i Beču [The influence of sociolinguistic factors on bilingual communities - Croatian bilingual communities in Istria and Wien]. Lahor: časopis za hrvatski kao materinski, drugi i strani jezik, 2(12), 175-196.

https://doi.org/10.3935/rsp.v21i1.1149

Hurtado, A., \& Gurin, P. (1987). Ethnic identity and bilingualism attitudes. Hispanic Journal of Behavioral Sciences, 9(1), 1-18. https://doi.org/10.1177/073998638703090101

Jaspal, R. (2009). Language and social identity: a psychosocial approach. Psych-Talk, 64, 17-20. Jelić, M., Čorkalo Biruški, D., \& Ajduković, D. (2014). Ideološki stavovi većinske grupe u dvije višeetničke sredine [Ideological attitudes of majority groups in two multi-ethnic environments]. Revija Za Socijalnu Politiku, 21(1), 19-41. 
https://doi.org/10.3935/rsp.v21i1.1149

Liebkind, K. (2010). Social psychology. In J. A. Fishman \& O. Garcia (Eds.), Language and ethnic identity ( $2^{\text {nd }}$ ed., pp. 18-32). Oxford university press.

Löw Stanić, A. (2014). Provjera postavki teorije međugrupne prijetnje u višeetničkoj zajednici nakon sukoba [Testing the intergroup threat theory in a multi-ethnic community after a severe conflict] (Doctoral dissertation, University of Zagreb).

http://darhiv.ffzg.unizg.hr/id/eprint/9184/1/Loew\%20Stanic_Disertacija_final.pdf

Mu, G. M. (2015). A meta-analysis of the correlation between heritage language and ethnic identity. Journal of Multilingual and Multicultural Development, 36(3), 239-254.

https://doi.org/10.1080/01434632.2014.909446

Mummendey, A., Klink, A., \& Brown, R. (2001). Nationalism and patriotism: National identification and out-group rejection. British Journal of Social Psychology, 40(2), 159172. https://doi.org/10.1348/014466601164740

Penic, S., Elcheroth, G., \& Morselli, D. (2017). Inter-group forgiveness in the aftermath of symmetric and asymmetric communal violence: Contact density and nationalistic climates as contextual mediators. European Journal of Social Psychology, 47(2), 209-227. https://doi.org/10.1002/ejsp.2248

Preacher, K. J., \& Hayes, A. F. (2008). Asymptotic and resampling strategies for assessing and comparing indirect effects in multiple mediator models. Behavior Research Methods, 40(3), 879-891. http://doi.org/10.3758/brm.40.3.879

Puth, M. T., Neuhäuser, M., \& Ruxton, G. D. (2015). On the variety of methods for calculating confidence intervals by bootstrapping. Journal of Animal Ecology, 84, 892-897. https://doi.org/10.1111/1365-2656.12382

R Core Team (2018). R: A language and environment for statistical computing. R foundation for statistical computing. http://www.R-project.org/ 
Riek, B. M., Mania, E. W., \& Gaertner, S. L. (2006). Intergroup threat and out-group attitudes: A meta-analytic review. Personality and Social Psychology Review, 10(4), 336-353. https://doi.org/10.1207/s15327957pspr1004_4

Riek, B. M., Mania, E. W., Gaertner, S. L., McDonald, S. A., \& Lamoreaux, M. J. (2010). Does a common in-group identity reduce intergroup threat? Group Processes and Intergroup Relations, 13(4), 403-423. https://doi.org/10.1177/1368430209346701

Roccas, S., Klar, Y., \& Liviatan, I. (2006). The paradox of group-based guilt: Modes of national identification, conflict vehemence, and reactions to the in-group's moral violations. Journal of Personality and Social Psychology, 91(4), 698-711. https://doi.org/10.1037/0022-3514.91.4.698

Rosseel, Y. (2012). Lavaan: An R package for structural equation modeling. Journal of Statistical Software, 48(2), 1-36. http://www.jstatsoft.org/v48/i02/

Ruttenberg, J., Zea, M., \& Sigelman, C. (1996). Collective identity and intergroup prejudice among Jewis and Arab students in the United States. Journal of Social Psychology, 136(2),209-220. https://doi.org/10.1080/00224545.1996.9713995

Schatz, R. T., Staub, E., \& Lavine, H. (1999). On the varieties of national attachment: Blind versus constructive patriotism. Political Psychology, 20(1), 151-174. https://doi.org/10.1111/0162-895X.00140

Stephan, W. G., Boniecki, K. A., Ybarra, O., Bettencourt, A., Ervin, K. S., Jackson, L. A., McNatt, P. S., \& Renfro, C. L. (2002). The role of threats in the racial attitudes of Blacks and Whites. Personality and Social Psychology Bulletin, 28(9), 1242-1254. https://doi.org/10.1177/01461672022812009

Stephan, W. G., \& Stephan, C. W. (1985). Intergroup anxiety. Journal of Social Issues, 41(3), 157-175. https://doi.org/10.1111/j.1540-4560.1985.tb01134.x

Stephan, W. G., \& Stephan, C. W. (2000). An integrated threat theory of prejudice. In S. Oskamp 
(Ed.), Reducing prejudice and discrimination (pp. 27-46). Lawrence Erlbaum.

Stephan, W. G., Ybarra, O., \& Rios Morrison, K. (2009). Intergroup threat theory. In T. D.

Nelson (Ed.), Handbook of prejudice, stereotyping, and discrimination (pp. 43-55).

Psychology Press.

Štambuk M, \& Čorkalo Biruški D. (2011). Active bystandership scale for adolescents.

Unpublished project documentation. Faculty of Humanities and Social Sciences.

Tajfel, H., \& Turner, J. C. (1979). An integrative theory of intergroup conflict. In W. G. Austin \& S. Worchel (Eds.), The social psychology of intergroup relations (pp. 33-47). BrooksCole.

Tong, Y. Y., Hong, Y. Y., Lee, S. L., \& Chiu, C. Y. (1999). Language use as a carrier of social identity. International Journal of Intercultural Relations, 23(2), 281-296.

https://doi.org/10.1016/S0147-1767(98)00039-X

Turner, J. C. (1975). Social comparison and social identity: Some prospects for intergroup behavior. European Journal of Social Psychology, 5(1), 1-34.

https://doi.org/10.1002/ejsp.2420050102

Verkuyten, M. (2005). Ethnic group identification and group evaluation among minority and majority groups: Testing the multiculturalism hypothesis. Journal of Personality and Social Psychology, 88(1), 121-138. https://doi.org/10.1037/0022-3514.88.1.121 


\section{Author Biographies}

Margareta Jelić is an Associate Professor of Social Psychology at the University of Zagreb. Her research interests are centered on identity processes, interpersonal and intergroup relations.

Ena Uzelac is a PhD student and Teaching Assistant at the University of Zagreb. Her research interests are focused on interethnic relations in multi-ethnic communities with an emphasis on a perception of threat from an out-group.

Dinka Čorkalo Biruški is a Professor of Social Psychology at the University of Zagreb. Her research interests are in the area of intergroup relation in war and peace. 